\title{
Utility of Crushed Stone Sand for Making Masonry Mortar
}

\author{
${ }^{* 1}$ Vijay Jhanwar \\ ${ }^{1}$ Design Unit, Water Ressources Department, Maharashtra State \\ Email:vsjhanwar@gmail.com
}

Received: 20th November 2019, Accepted: 10th February 2020, Published: 29th February 2020

\begin{abstract}
This paper deals with assessing suitability of crushed stone sand in replacement of natural sand for making of masonry mortar. For an internal study at Maharashtra Engineering Research Institute Nashik, five types of masonry mortar specimens $(1: 2,1: 3,1: 4,1: 5 \& 1: 6)$ were cast in the laboratory using natural sand \& OPC 43 conforming to IS 8112 - 1989. Likewise, exactly five similar types of masonry mortar specimens were cast using crushed stone sand \& OPC 43.Applying the same concept, similar five types of masonry mortar specimens with same mix proportions as used above were cast using natural sand \& PPC conforming to IS 1489 (Part 1) - 1991. Likewise, exactly five similar types of masonry mortar specimens were cast using crushed stone sand \& PPC.Compressive strengths at various ages were observed for each masonry mortar specimen.

Comparative study reveals that crushed stone sand can be used in replacement of natural sand for making of masonry mortar if it satisfies the specifications laid down in IS $2116-1980$ [7] and also it is available at lower price as compared to natural sand.
\end{abstract}

Keywords

Crushed Stone Sand, Masonry Mortar, PPC, Natural Sand, OPC

\section{Necessity of the Research}

It is observed that availability of natural sand is being reduced day by day due to construction of various dams having un-gated or inadequately gated spillways. Also the demand is continuously increasing due to rapid infrastructure development. So, acute shortage of natural sand is to be overcome by provision of alternative fine aggregate i.e. crushed stone sand. [8]

\section{Methodology for Experimental Study}

For effective comparison, it would have been logical to provide same quantities of water and cement for each category of mortar mix made with natural sand \& crushed stone sand. But in case of mortar, flow plays major role in deciding its suitability for intended use. Hence, flow was kept same $(110-115 \%)$ for each category of mix made with natural sand and crushed stone sand as per guidelines given in appendix A - 4 on p. no. 22 of IS 2250-1981.[1] Flow table used was as per IS 5512-1983. [4] Thus, taking all other ingredients in same quantity (except water), one mix was cast using natural sand (with OPC \& PPC each) and other mix was cast using crushed stone sand (with OPC \& PPC each) as per guidelines given in IS 2250-1981. [5][6] Total 10 mixes were cast using natural sand \& 10 using crushed stone sand. The proportions of cement $\&$ sand adopted were 1:2, 1:3, 1:4, 1:5 \& 1:6 by mass. Mix proportions and properties of all mixes referred above are mentioned in table no. 1 . Also, graphs (no. 1 to 5) are plotted for comparing the compressive strengths at various ages. [2][3] 
Tables and Graphs

\begin{tabular}{|c|c|c|c|c|c|c|c|c|c|c|c|c|}
\hline \multirow{3}{*}{$\begin{array}{l}\text { Sr } \\
\text { No }\end{array}$} & \multirow{3}{*}{$\begin{array}{c}\text { Notation } \\
\text { of } \\
\text { motar } \\
\text { mix. }\end{array}$} & \multicolumn{5}{|c|}{$\begin{array}{l}\text { Proportions of various ingredients of } \\
\text { mortar in kg. }\end{array}$} & \multirow{3}{*}{$\begin{array}{l}\text { Flow } \\
(\%)\end{array}$} & \multicolumn{5}{|c|}{ Compressive Strength of mortar in N/mm } \\
\hline & & \multicolumn{2}{|c|}{ Cement } & \multirow{2}{*}{$\begin{array}{c}\text { Water } \\
\text { Litre }\end{array}$} & \multicolumn{2}{|c|}{ Fine Aggregate } & & \multirow[b]{2}{*}{3 days } & \multirow[b]{2}{*}{7 days } & \multirow[b]{2}{*}{14 days } & \multirow[b]{2}{*}{28 days } & \multirow[b]{2}{*}{90 days } \\
\hline & & $\begin{array}{c}\text { OPC } \\
43\end{array}$ & PPC & & $\begin{array}{c}\text { Natural } \\
\text { sand }\end{array}$ & \begin{tabular}{|c|}
$\begin{array}{c}\text { Crushed } \\
\text { stone } \\
\text { sand. }\end{array}$ \\
\end{tabular} & & & & & & \\
\hline 1 & $\mathrm{NO}-1: 2$ & 1 & - & 0.345 & 2 & - & 115 & 23.43 & 28.47 & 36.17 & 40.25 & 56.32 \\
\hline 2 & $\mathrm{CO}-1: 2$ & 1 & - & 0.425 & - & 2 & 115 & 27.94 & 34.69 & 41.83 & 47.61 & 66.93 \\
\hline 3 & NP - 1:2 & - & 1 & 0.340 & 2 & - & 115 & 15.71 & 17.13 & 28.26 & 35.29 & 43.87 \\
\hline 4 & CP - 1:2 & - & 1 & 0.420 & - & 2 & 115 & 13.91 & 17.94 & 30.07 & 36.63 & 49.53 \\
\hline 5 & NO - 1:3 & 1 & - & 0.455 & 3 & - & 110 & 18.95 & 21.60 & 32.54 & 35.91 & 44.40 \\
\hline 6 & $\mathrm{CO}-1: 3$ & 1 & - & 0.550 & - & 3 & 110 & 19.73 & 22.62 & 33.12 & 39.54 & 46.60 \\
\hline 7 & $N P-1: 3$ & - & 1 & 0.450 & 3 & - & 115 & 12.72 & 13.90 & 19.76 & 33.90 & 38.36 \\
\hline 8 & $C P-1: 3$ & - & 1 & 0.550 & - & 3 & 115 & 11.50 & 12.12 & 18.34 & 31.70 & 36.11 \\
\hline 9 & NO - 1:4 & 1 & - & 0.585 & 4 & - & 115 & 9.14 & 11.33 & 17.33 & 23.57 & 29.81 \\
\hline 10 & CO - 1:4 & 1 & - & 0.680 & - & 4 & 115 & 8.13 & 12.32 & 17.13 & 23.39 & 28.91 \\
\hline 11 & NP - 1:4 & - & 1 & 0.585 & 4 & - & 115 & 5.39 & 8.13 & 12.52 & 20.37 & 25.71 \\
\hline 12 & $C P-1: 4$ & - & 1 & 0.675 & - & 4 & 115 & 6.73 & 9.01 & 14.30 & 21.93 & 27.20 \\
\hline 13 & NO - 1:5 & 1 & - & 0.705 & 5 & - & 115 & 5.72 & 9.34 & 12.91 & 19.36 & 26.19 \\
\hline 14 & $\mathrm{CO}-1 ; 5$ & 1 & - & 0.800 & - & 5 & 115 & 4.98 & 8.94 & 12.12 & 18.32 & 25.24 \\
\hline 15 & NP - 1:5 & - & 1 & 0.695 & 5 & - & 115 & 3.97 & 7.33 & 11.61 & 16.32 & 23.04 \\
\hline 16 & CP - 1:5 & - & 1 & 0.785 & - & 5 & 115 & 4.33 & 7.93 & 11.92 & 16.91 & 23.62 \\
\hline 17 & NO - 1:6 & 1 & - & 0.810 & 6 & - & 115 & 4.92 & 7.93 & 9.94 & 15.92 & 20.17 \\
\hline 18 & Co - 1:6 & 1 & - & 0.910 & - & 6 & 115 & 4.69 & 7.13 & 9.74 & 15.71 & 19.93 \\
\hline 19 & NP - 1:6 & - & 1 & 0.800 & 6 & - & 115 & 1.81 & 4.15 & 7.13 & 10.93 & 17.13 \\
\hline 20 & $C P-1: 6$ & - & 1 & 0.900 & - & 6 & 115 & 2.71 & 4.72 & 8.94 & 11.92 & 18.95 \\
\hline
\end{tabular}

$\mathrm{NO}$ - Mortar made with natural sand \& OPC

CO - Mortar made with crushed stone sand \& OPC

NP - Mortar made with natural sand \& PPC

CP - Mortar made with crushed stone sand \& PPC

Table 1: Mix Proportions and Compressive Strength of Mortars 


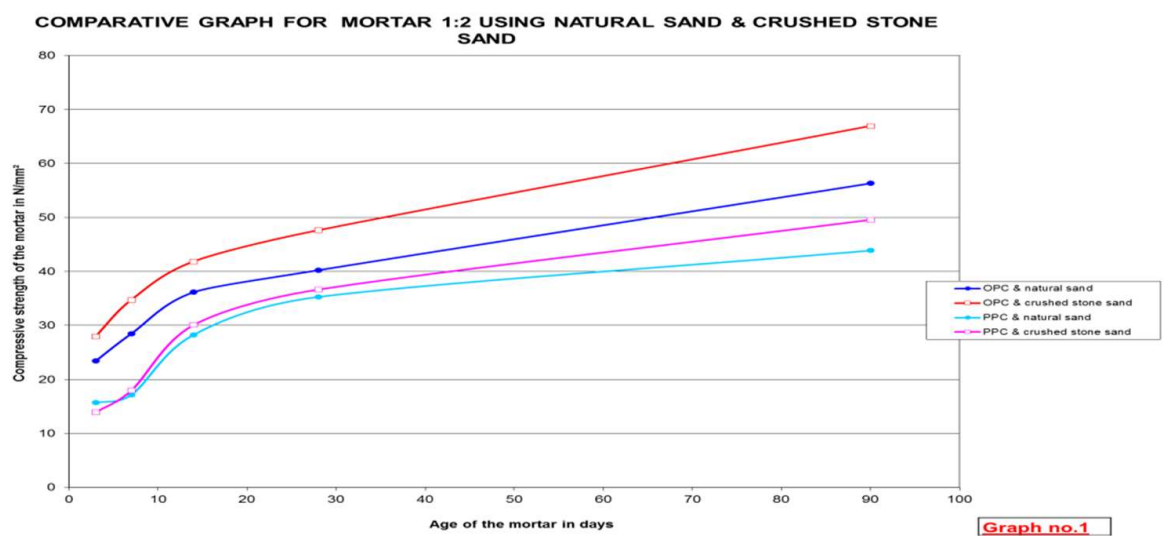

Graph1: Mortar 1:2

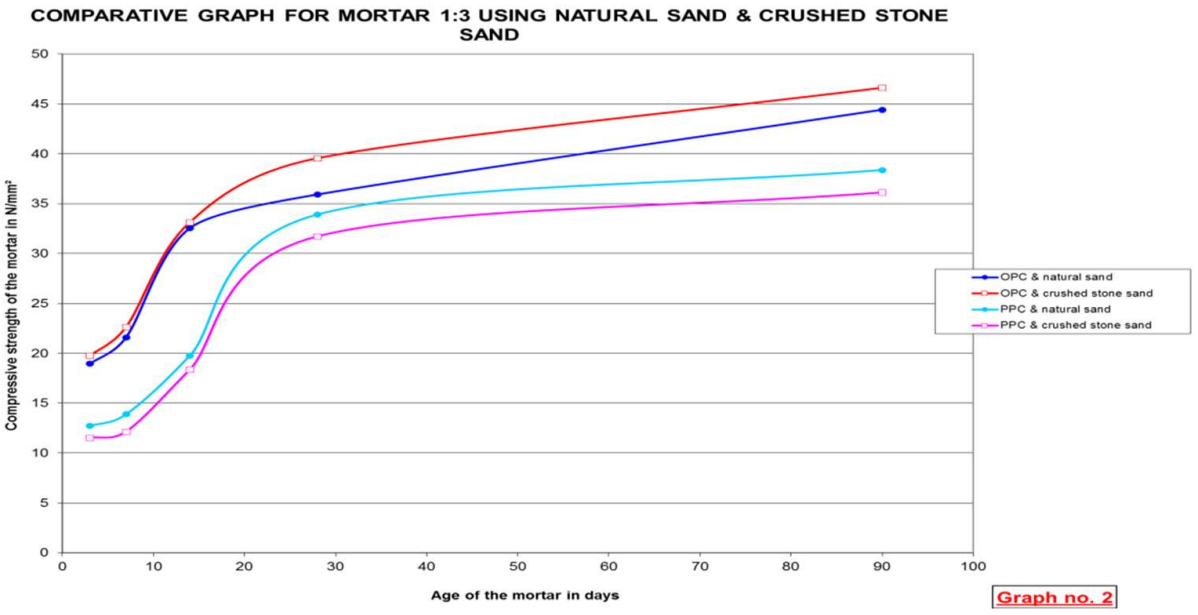

Graph 2: Mortar 1:3

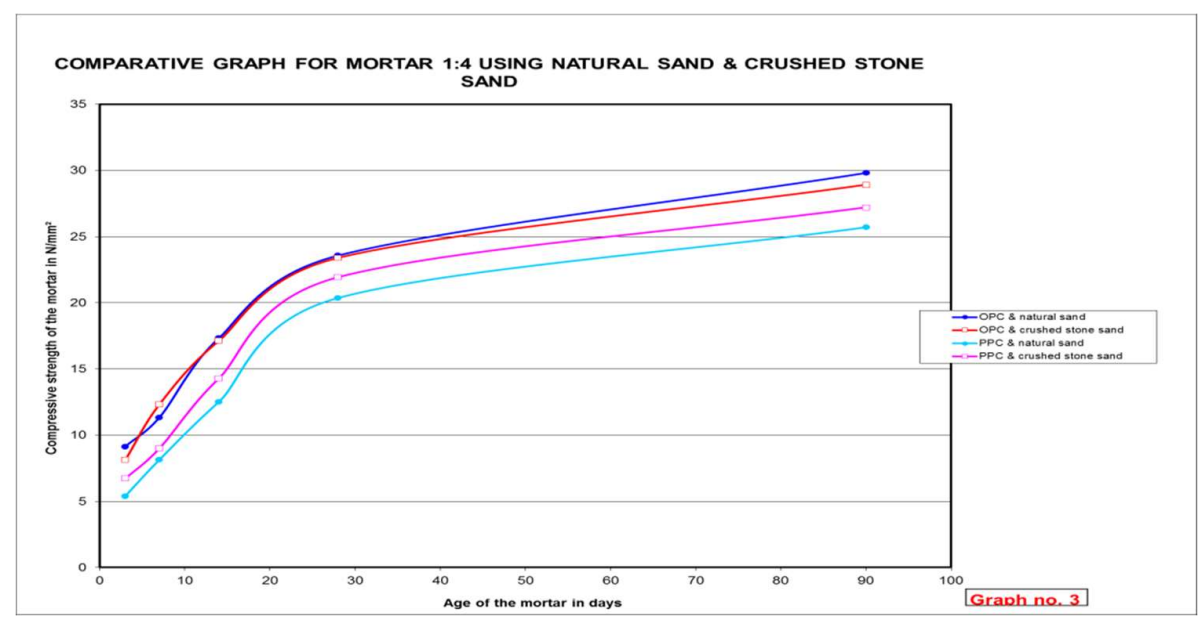

Graph 3: Mortar 1:4 


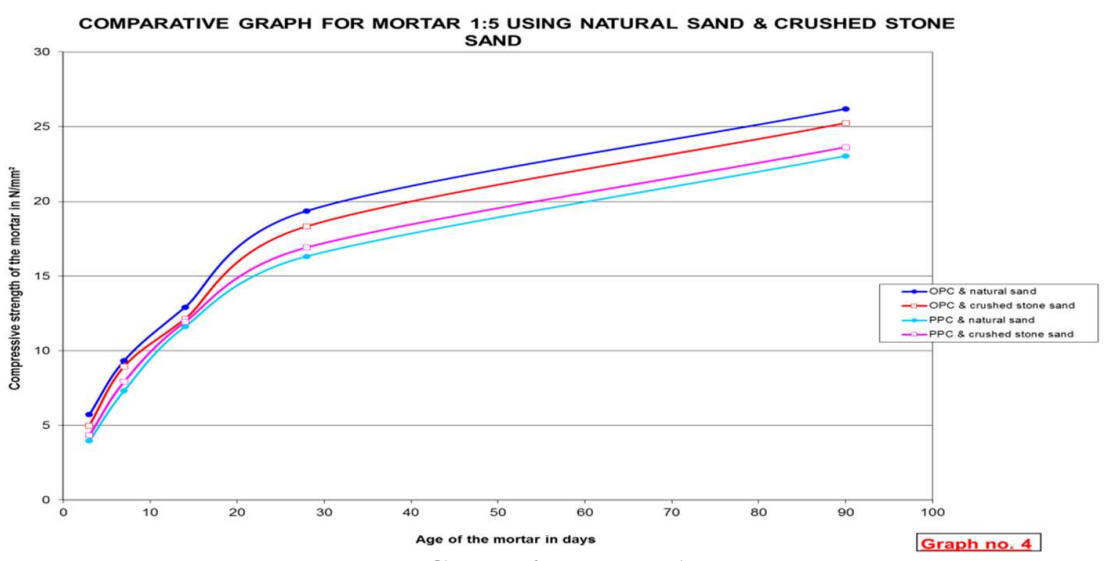

Graph 4: Mortar 1:5

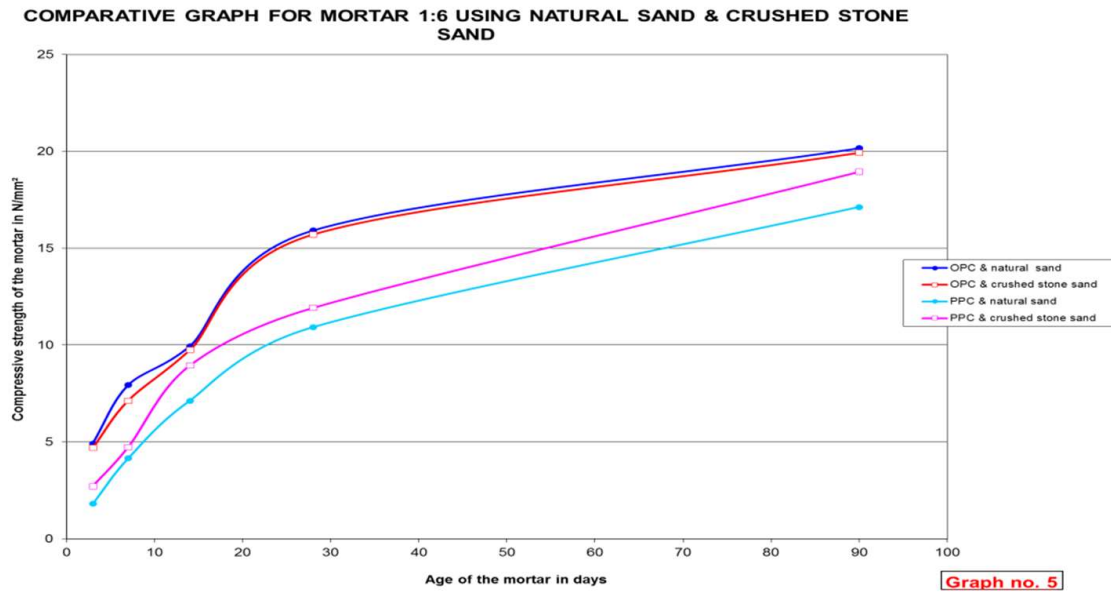

\section{Result and Discussion}

Graph 5: Mortar 1:6

1) For rich mortar mixes (1:2 \& 1:3), water requirement is 23.2 and $20.9 \%$ more if crushed stone sand is used in lieu of natural sand. Yet the compressive strength is more as compared to the mix using natural sand.

2) For lean mortar mixes (1:4, 1:5 \& 1:6), water requirement is about 16.2, 13.5 and $12.3 \%$ more if crushed stone sand is used in lieu of natural sand. Yet the compressive strength is almost same or slightly less as compared to the mix using natural sand.

\section{Conclusion}

Various compressive strength tests carried out in MERI laboratory indicates that Crushed stone sand may be used in lieu of natural sand for making of masonry mortar if it satisfies all the specifications given in IS 21161980 and also it is available at lower price as compared to natural sand.

\section{References}

1. Specification For Ordinary Portland Cement 43 Grade I.S. 8112 - 1989

2. Specification For Portland Pozzolana Cement - Fly Ash Based I.S. 1489 (part 1) - 1991

3. Code Of Practice For Preparation \& Use Of Masonry Mortars I.S. 2250 - 1981

4. Specification For Sand For Masonry Mortar I.S. 2116 - 1980

5. Specification For Flow Table For Use In Tests Of Hydraulic Cements \& Pozzolanic Materials I.S.5512-1983

6. Concrete Technology (M.S. Shetty)

7. Properties of concrete (A.M. Neville)

8. Technical Report No MTD/284, Maharashtra Engineering Research Institute, Nashik - June 2011 